\title{
Heart-lung crosstalk in pulmonary arterial hypertension following myocardial infarction (Review)
}

\author{
WENFENG YE ${ }^{1,2^{*}}$, HAIXU GUO ${ }^{1,2^{*}}$, JINRONG XU $^{3 *}$, SHUYUN CAI $^{4}$, YUAN HE $^{1}$, \\ XIAORONG SHUI ${ }^{5}$, SHIAN HUANG ${ }^{2}$, HUI LUO ${ }^{6}$ and WEI LEI ${ }^{1,2,6}$ \\ ${ }^{1}$ Laboratory of Cardiovascular Diseases, Guangdong Medical University; ${ }^{2}$ Cardiovascular Medicine Center, \\ Affiliated Hospital of Guangdong Medical University; ${ }^{3}$ Department of Cardiovascular Internal Medicine, \\ The Second Affiliated Hospital of Guangdong Medical University; ${ }^{4}$ Department of Anesthesiology, Affiliated Hospital \\ of Guangdong Medical University, Zhanjiang, Guangdong 524001; ${ }^{5}$ Laboratory of Vascular Surgery, \\ Guangdong Medical University; ${ }^{6}$ Southern Marine Science and Engineering Guangdong Laboratory-Zhanjiang, \\ The Marine Biomedical Research Institute, Guangdong Medical University, Zhanjiang, Guangdong 524000, P.R. China
}

Received January 26, 2020; Accepted May 4, 2020

DOI: $10.3892 /$ ijmm.2020.4650

\begin{abstract}
Left heart disease is the main cause of clinical pulmonary arterial hypertension (PAH). Common types of left heart disease that result in PAH include heart failure, left ventricular systolic dysfunction, left ventricular diastolic dysfunction and valvular disease. It is currently believed that mechanical pressure caused by high pulmonary venous pressure is the main cause of myocardial infarction (MI) in individuals with ischemic cardiomyopathy and left ventricular systolic dysfunction. In the presence of decreased cardiac function, vascular remodeling of pulmonary vessels in response to long-term stimulation by high pressure in turn leads to exacerbation of PAH. However, the underlying pathological mechanisms remain unclear. Elucidating the association between the development of MI and PAH may lead to a better understanding of potential risk factors and better disease treatment. In this article, the pathophysiological effects of multiple systems in individuals with MI and PAH were reviewed in order to provide a general perspective on various potential interactions between cardiomyocytes and pulmonary vascular cells.
\end{abstract}

Correspondence to: Dr Wei Lei, Laboratory of Cardiovascular Diseases, Guangdong Medical University, 57 Renmin Southern Road, Xiashan, Zhanjiang, Guangdong 524001, P.R. China E-mail: leiwei2006@126.com

Dr Shian Huang, Cardiovascular Medicine Center, Affiliated Hospital of Guangdong Medical University, 57 Renmin Southern Road, Xiashan, Zhanjiang, Guangdong 524001, P.R. China

E-mail: huangshian2013@yahoo.com

${ }^{*}$ Contributed equally

Key words: pulmonary arterial hypertension, myocardial infarction, cardiomyocyte, vascular endothelial cells, interaction

\section{Contents}

1. Introduction

2. Renin-angiotensin system

3. Reactive oxygen species

4. Endothelin-1

5. Vascular endothelial growth factor

6. Bone morphogenetic protein

7. Adiponectin

8. Conclusions

\section{Introduction}

Pulmonary arterial hypertension (PAH), a chronic lung disease with poor prognosis, is characterized by progressively increasing blood pressure in the pulmonary vasculature. The normal resting mean pulmonary arterial pressure in healthy adults is $\sim 14 \mathrm{mmHg}$ at rest, whereas it is $>25 \mathrm{mmHg}$ in adults with PAH (1). PAH is usually secondary to conditions such as collagen vascular diseases, cardiac malformations and viral infections, and is currently believed to be associated with endothelial dysfunction, vasoconstriction and pulmonary vascular remodeling. Endothelial dysfunction, which is associated with an imbalance between vasodilators [e.g., nitric oxide (NO) and prostacyclin] and vasoconstrictors [e.g., endothelin (ET), thromboxane A2 and serotonin], is considered to be an early event during the process of PAH (2). A series of events leads to excessive proliferation of lung smooth muscle cells, activation of lung fibroblasts, induction of thrombotic mediators and release of inflammatory cytokines, all of which increase pulmonary vascular resistance and stress. One cause of vascular endothelial dysfunction and vascular injury is activation of the renin-angiotensin system (RAS). This results in overactivation of the angiotensin-converting enzyme (ACE)-angiotensin II (Ang II)-angiotensin II receptor type 1 (AT1R) axis, which involves ACE, vasoactive peptides and blood vessels. Ang II and its receptor, AT1R, exert adverse 
effects on pulmonary hemodynamics and may cause PAH (3). Myocardial infarction (MI) may lead to post-capillary PAH, increased left ventricular filling pressure, ventricular remodeling, even heart failure $(4,5)$. Left ventricular failure leads to an increase in PAH and right ventricular afterload, which, in turn, leads to right ventricular remodeling and dysfunction. The PAH caused by left heart disease is mainly associated with left ventricular systolic or diastolic dysfunction or valvular heart disease, and has a poor prognosis $(1,6)$. Persistent high pulmonary pressure may worsen endothelial dysfunction, reduce NO utilization and increase ET expression (4). Early-stage PAH associated with left heart disease may be reversible. However, the cardiac remodeling associated with long-term PAH may prevent reversal of PAH. PAH is the most common complication of congestive heart failure (7). Both hemodynamic factors and various molecular mechanisms contribute to the development of PAH after MI. In particular, in individuals with chronic PAH, a combination of mechanical pressure and histopathological reactions promotes progression of PAH, which ultimately becomes irreversible. The aim of the present review was to provide a comprehensive overview of the pathophysiological effects of multiple systems in MI and $\mathrm{PAH}$, particularly regarding interactions between cardiomyocytes (CMs) and pulmonary vascular cells in post-MI PAH.

\section{Renin-angiotensin system}

There is considerable evidence that the RAS contributes to the pathogenesis of PAH. High concentrations of renin, ACE, Ang II and AT1R have been documented in experimental models, as well as in patients with PAH (8-11). Increased activity of the RAS, systemically and in the pulmonary circulatory system, may adversely affect heart and lung function and contribute to disease progression. However, drugs that block the classical RAS, such as ACE inhibitors and AT1R blockers, reportedly have adverse effects when used to treat $\mathrm{PAH}$, including drug-induced systemic hypotension, cough and angioedema (12). The advisability of blocking the RAS is controversial, as it plays a vasoprotective role in certain cardiovascular diseases.

As the pulmonary vasculature is more sensitive compared with the systemic vasculature to the contractile effects of AngII $(8,9)$, AngII plays an important role in the pulmonary vascular circulation. Myocardial tissue can express RAS locally via a paracrine pathway (13). MI can trigger activation of the RAS, the long-term activation of which may cause myocardial damage; in this setting, AngII exerts a negative effect (14). When the circulating blood volume or renal blood flow is reduced, the paracellular cells of the juxtaglomerular apparatus secrete renin into the blood. This hydrolyzes the angiotensinogen produced by the liver into the decapeptide angiotensin I (AngI). In the pulmonary circulation, AngI is hydrolyzed to the octapeptide AngII by a converting enzyme present in the endothelial cells (ECs) of the pulmonary vasculature. AngII exerts different biological effects by binding to two subtype receptors, namely AT1R and AT2R. AT1R causes vasoconstriction, cell proliferation, inflammation and fibrosis through the ACE/AngII/AT1R signaling pathway, whereas AT2R protects the lungs through the ACE2/Ang-(1-7)/Mas receptor signaling pathway $(15,16)$. In patients with $\mathrm{PAH}$, as well as in experimental models, renin, AngII, ACE and AT1R are all increased to varying degrees in the blood. Additionally, the ratio of AT1R/AT2R and the expression of AT1R are increased $(11,17)$. However, it remains unclear whether the increase in the levels of these hormones is a direct result of $\mathrm{PAH}$, or whether it is mainly caused by the decrease in cardiac function caused by PAH.

Increased expression of AT1R and AT2R has been demonstrated in CMs in non-infarcted areas following MI. In vitro, acidosis promotes death of CMs and AngII enhances this effect (18). There is increasing evidence that AngII induces apoptosis of lung parenchymal cells, causing pulmonary vascular remodeling that ultimately leads to PAH, and that it also induces hypertrophy of CMs, inflammation and fibrosis during cardiac ischemic injury. This leads to ventricular remodeling and further impairment of cardiac function $(12,19)$. It has been established that RAS is activated by a decline in cardiac function after MI, and that PAH is caused by both mechanical pressure and contraction mediated by AngII and vascular remodeling. The resultant further impairment of cardiac function in turn promotes the development of PAH $(18,20)$. The initiation and development of chronic PAH originate from pulmonary vascular EC dysfunction. Endothelial damage increases the production of AngII in lung tissue (20), which both exacerbates contraction and remodeling of pulmonary vessels and adversely affects CMs. The evidence mentioned above indicates that AngII plays an important role in both MI and PAH. Of note, there are different degrees of AT1R/AT2R imbalance in MI and PAH. These findings indicate that there is a vicious circle between myocardial damage and pulmonary vascular response; they also provide a new perspective on the association between myocardial and pulmonary blood vessels. Further study of these mechanisms may indicate new approaches to the effective treatment of PAH (Fig. 1).

\section{Reactive oxygen species}

Reactive oxygen species (ROS) play a key role in regulating contraction/expansion, cell growth, apoptosis, migration, inflammation and fibrosis. Superoxide anions, hydrogen peroxide, hydroxyl radicals, reactive nitrogen, NO and peroxynitrite all serve important biological roles in the cardiovascular system. NADPH oxidase 2 (NOX2), which is a major source of ROS in the heart, is activated by MI, resulting in the generation of large amounts of ROS. NOX may be activated by several other noxious stimuli, including AngII, tumor necrosis factor (TNF)- $\alpha$, vascular endothelial growth factor (VEGF) and shear stress (21). In addition, under hypoxic conditions, oxygenated myoglobin in CMs can produce an abundance of ROS (22). After an MI, ROS increase significantly in non-infarcted myocardium. Pulmonary blood vessels may be stimulated by the resultant changes in blood flow (23). Increased ROS production is involved in ventricular remodeling and heart failure after MI. A growing body of evidence supports the role of large amounts of ROS in the development and progression of PAH. Increased amounts of oxidative stress markers have been detected in the urine and plasma of patients with PAH. Additionally, histological examination of lung sections from such patients has revealed large amounts of by-products of oxidative stimuli $(24,25)$. Experimental 


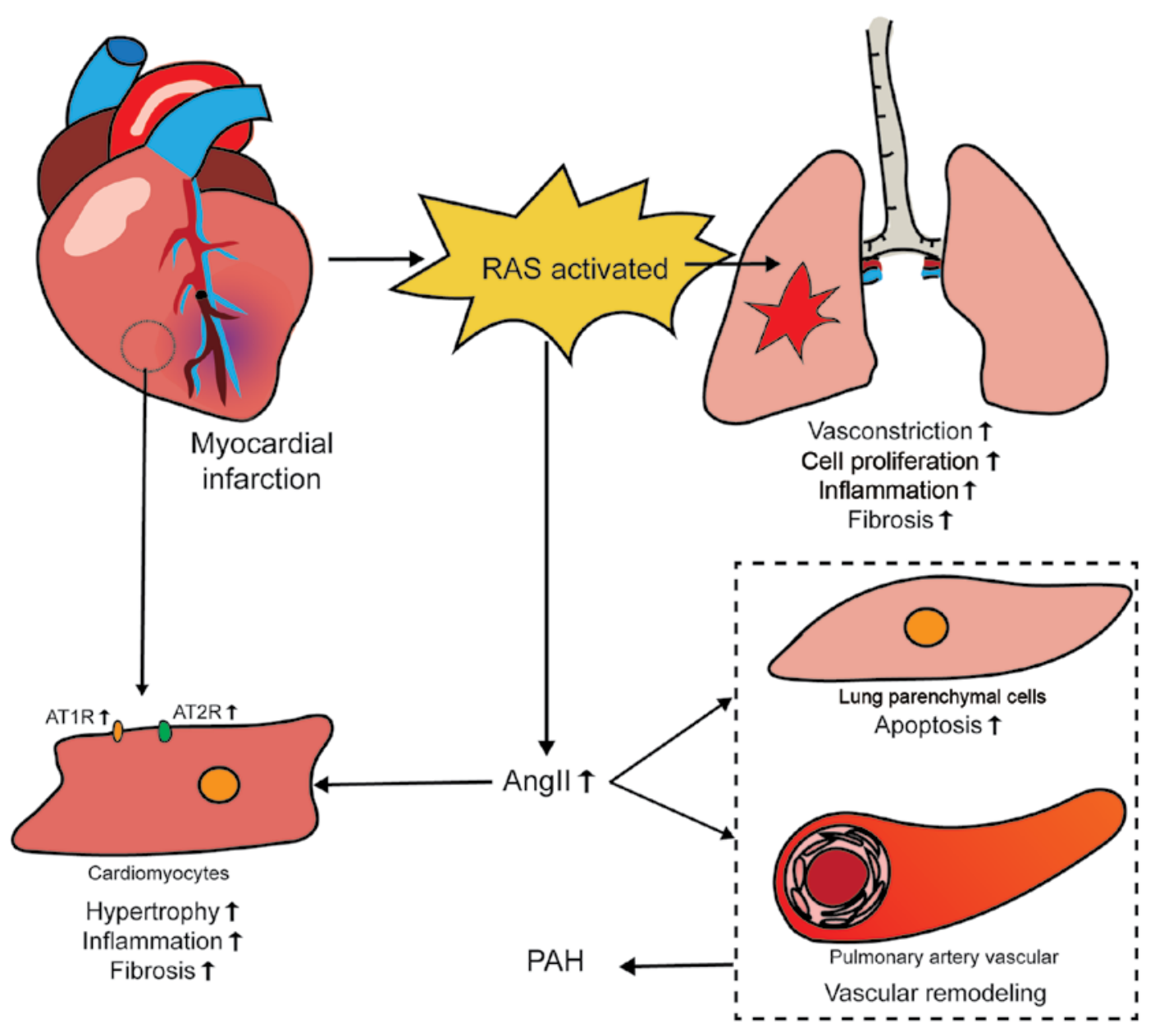

Figure 1. Role of the RAS system in the crosstalk between the heart and lung. RAS, renin-angiotensin system; AngII, angiotensin II; PAH, pulmonary arterial hypertension; AT1R, angiotensin II receptor type 1; AT2R, angiotensin II receptor type 2.

reduction of ROS levels combined with the use of antioxidants may enhance the response to the vasodilator NO in the pulmonary arteries. Inhibition of NOX or treatment with ROS scavengers may inhibit the development of chronic hypoxic PAH (26). ROS can reportedly promote pyruvate kinase M2 (PKM2) phosphorylation and inhibit the glycolytic activity of PKM2. This leads to proliferation of pulmonary artery smooth muscle cells (PASMCs) and maintenance of their antioxidant responses (27). Excessive ROS generation not only promotes AngII-mediated vascular remodeling, but also reduces vascular responses to NO. ROS have been demonstrated to play a key role in promoting the proliferation of pulmonary artery smooth muscle and EC damage associated with PAH (28). Pulmonary vascular ECs can also produce ROS. Additionally, ROS may act as signaling molecules that induce an increase in the amount of intracellular $\mathrm{Ca}^{2+}$, including in the cytoplasm of pulmonary ECs, which causes cell damage (26). Of note, AngII is also involved in the pathogenesis of ROS-mediated myocardial and pulmonary vascular cell damage and plays a key role in the cardiovascular system by activating NOX on cell membranes (29). AngII not only exacerbates CM injury to through direct action, but also promotes apoptosis of pulmonary parenchymal and vascular cells and pulmonary vascular remodeling, which stimulates almost all types of vascular cells to produce large amounts of ROS (30). There is some evidence that ROS produced post-MI can affect lung ECs and that
AngII is also involved in ROS-mediated EC injury. However, the pathological mechanism of post-MI PAH has not been studied and warrants investigation. In PAH, large amounts of ROS are harmful to the already damaged heart, which further impairs cardiac function. Deterioration in cardiac function increases blood flow shear force in the pulmonary arteries, which impairs pulmonary vascular function (Fig. 2).

\section{Endothelin-1}

Endothelin (ET) has three isoforms, namely ET-1, -2 and -3.ET receptors are differentially expressed among different tissues and organs, and they are coupled with at least four known $\mathrm{G}$ proteins, the resultant complexes being $\mathrm{ET}_{\mathrm{A}}, \mathrm{ET}_{\mathrm{B} 1}, \mathrm{ET}_{\mathrm{B} 2}$ and $\mathrm{ET}_{\mathrm{C}} \cdot \mathrm{ET}_{\mathrm{B} 1}, \mathrm{ET}_{\mathrm{B} 2}$ and $\mathrm{ET}_{\mathrm{C}}$ have different binding affinities (31). The ET pathway in the pulmonary circulation is composed of ET-1, $\mathrm{ET}_{\mathrm{A}}$ and $\mathrm{ET}_{\mathrm{B}}$ (i.e., $\mathrm{ET}_{\mathrm{B} 1}$ and $\mathrm{ET}_{\mathrm{B} 2}$ ), with $\mathrm{ET}-1$ exhibiting high-affinity binding (32). $\mathrm{ET}_{\mathrm{A}}$ and $\mathrm{ET}_{\mathrm{B}}$ receptors are present in smooth muscle cells and promote vasoconstriction and cell proliferation. $\mathrm{ET}_{\mathrm{B}}$ receptors are also present in $\mathrm{ECs}$; however, they promote vasodilation by releasing NO, prostacyclin and other endothelium-dependent vasodilators. Endogenous ET-1 mainly exerts its vasoconstrictive effect through $\mathrm{ET}_{\mathrm{B}}$ on smooth muscle cells. However, the role of $\mathrm{ET}_{\mathrm{A}}$ in the pulmonary vascular circulation has not yet been clearly determined (33-36). 


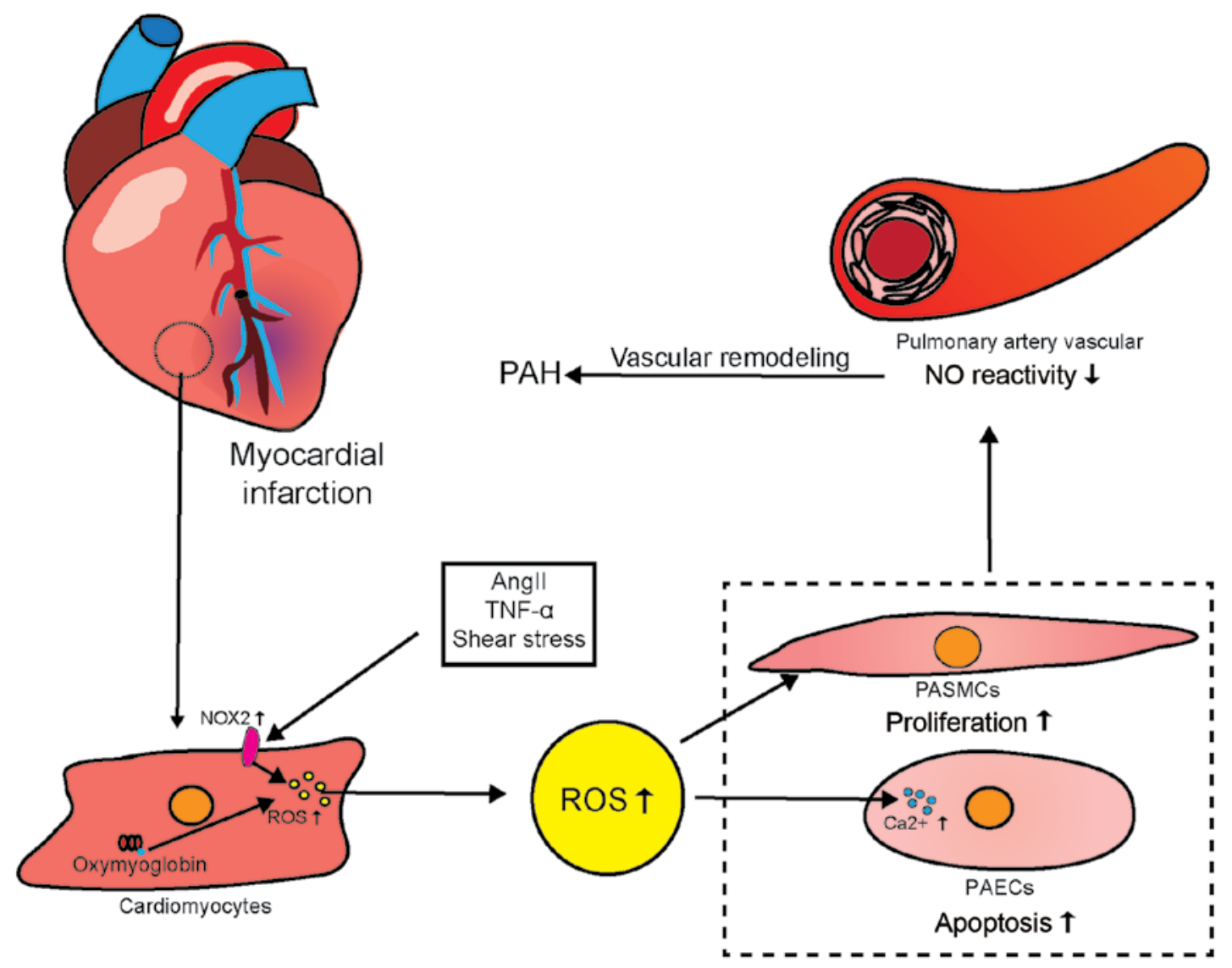

Figure 2. Role of ROS in the crosstalk between the heart and lung. ROS, reactive oxygen species; PAH, pulmonary arterial hypertension; AngII, angiotensin II; TNF, tumor necrosis factor; NO, nitric oxide; NOX2, NADPH oxidase 2; PASMCs, pulmonary artery smooth muscle cells; PAECs, pulmonary artery endothelial cells.

Enhancement of ET system activity is associated with the severity of PAH. ET receptor antagonists have therefore been used clinically to treat PAH. They have been shown to have beneficial effects on PAH morbidity and mortality, emphasizing the important role of ET-1 in the development of PAH. The drug treatment of PAH is currently in its early stages, and there are currently no known drugs that can completely reverse PAH. However, two drugs appear to be somewhat effective, namely the dual $\left(\mathrm{ET}_{\mathrm{A}}\right.$ and $\left.\mathrm{ET}_{\mathrm{B}}\right) \mathrm{ET}$ receptor antagonist bosentan and the selective ET receptor antagonist ambristan. However, their efficacy is restricted by their limited ability to penetrate tissue (37-39). Expression of ET-1 is mainly detected in the ECs of the pulmonary artery and may lead to intimal fibrosis and thickening of the media. Increased immunoreactivity of ET-1 in the pulmonary microcirculation and high plasma concentrations of ET-1 are directly associated with high right atrial pressure, low pulmonary oxygen saturation, and high pulmonary vascular resistance. Accumulating evidence suggests that ET-1 is pathophysiologically involved in the development of myocardial ischemia and infarction. It has been demonstrated that plasma ET-1 concentrations are significantly higher in patients with MI compared with those in healthy individuals (40).

Current research indicates that ET-1 plays an important role in vasoconstriction and pulmonary microcirculation remodeling. van Duin et al performed pulmonary vein banding on pigs and found that, over time, pulmonary artery pressure and resistance increased significantly. Pre-ET-1 and
ET-converting enzyme-1 also increased in the lungs, as did ET mRNA expression, with resultant pulmonary vasoconstriction. However, sensitivity to ET decreased with increased pulmonary vascular contractility, which indicates that ET-1 plays an important role in pulmonary vascular remodeling in post-MI PAH (41). Similarly, in a study using a swine model of MI, Merkus et al observed stronger ET-mediated vasoconstriction in the pulmonary circulation, decreased bioavailability of NO, and impairment of the vasodilation mediated by prostaglandin compared with swine without MI. All these changes could be normalized by $\mathrm{ET}_{\mathrm{A}} / \mathrm{ET}_{\mathrm{B}}$ receptor blockade (42). Satwiko et al used ET transgenic mice to study the correlation between PAH and ET and found that targeted activation of ET-1 exacerbated hypoxia-induced PAH. Their findings indicate that the pulmonary arteries are more susceptible to ET-1-mediated vasoconstriction compared with the systemic arteries, which further emphasizes the importance of ET-1 in the development of PAH (43). Others have also reported evidence that enhanced ET system activity may be a causative factor in the development of PAH $(44,45)$, which provides a theoretical basis for treating PAH by inhibiting the ET system.

ET-1 is synthesized and released from blood vessels and endocardial ECs, as well as muscle cells. Of note, in patients with coronary artery spasm, MI and congestive heart failure, the amounts of ET-1 increase to varying degrees. In a porcine myocardial ischemia model, it was found that even transient blockage of coronary blood flow resulted in increased ET-1 production (10). It has also been reported that the 

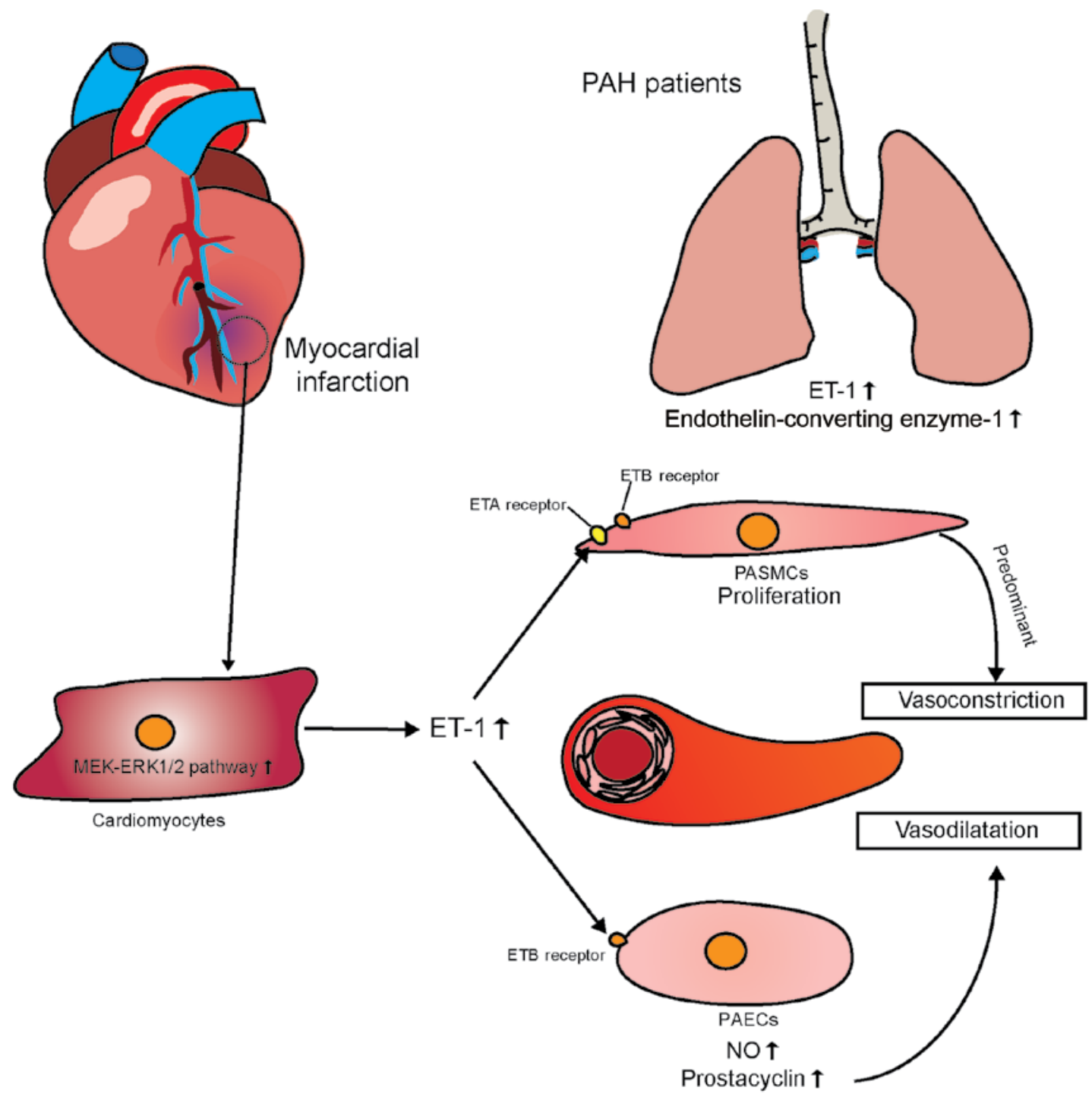

Figure 3. Role of ET-1 signals in the crosstalk between the heart and lung. ET, endothelin; PAH, pulmonary arterial hypertension; NO, nitric oxide; PASMCs, pulmonary artery smooth muscle cells; PAECs, pulmonary artery endothelial cells; MEK-ERK1/2, mitogen-activated protein kinase/extracellular signal-regulated kinase.

mitogen-activated protein kinase/extracellular signal-regulated kinase (MEK-ERK1/2) signaling pathway was a key regulator of ET-1 and $\mathrm{ET}_{\mathrm{B}}$ receptors in the myocardium and coronary arteries after ischemia-reperfusion (I/R) in a rat model (40). Myocardial cells are subject to ischemia. Reperfusion stimulation enhances transcriptional expression of ET-1 and vasoconstrictive $\mathrm{ET}_{\mathrm{B}}$ receptors via the MEK-ERK1/2 signal transduction pathway. The vasoconstrictor response to ET-1 in the heart is mainly mediated by $\mathrm{ET}_{\mathrm{A}}$ receptors in vascular smooth muscle cells (VSMCs), whereas vasodilation is mediated by $\mathrm{ET}_{\mathrm{B}}$ receptors located in the endothelium. It has been demonstrated that there is a phenotypic transformation of $\mathrm{ET}_{\mathrm{B}}$ receptors in coronary VSMCs, the phenotype changing from diastolic to contractile (46); this means that, in the case of myocardial injury, ET-1 may cause coronary artery contraction and exacerbate myocardial ischemia through systolic $\mathrm{ET}_{\mathrm{B}}$ receptors. It remains unclear whether the ET-1 pathway is directly involved in the development of PAH following myocardial ischemic injury. Additionally, additional incompletely characterized intercellular interactions may be responsible for the failure to develop effective treatments for PAH (Fig. 3).

\section{Vascular endothelial growth factor}

VEGFs, a family comprising VEGF-A, -B, -C, -D and -E, and placental growth factor, are named in accordance with the number of constituent amino acids, e.g., VEGF121 and VEGF145. VEGF165 is the predominant VEGF-A isoform, the others being VEGF165, VEGF189 and VEGF206 (47). VEGF-A promotes vascular EC growth and migration and induces angiogenesis in a variety of in vivo animal models. VEGF-A165 is the most abundant and biologically active VEGF-A isoform. VEGF-A165 is primarily expressed in a variety of tumors, and its expression level is associated with tumor activity (e.g., development, invasion and metastasis) (48). The VEGF receptor (VEGFR) family consists of three subtypes: VEGFR-1, -2 and -3. All three receptor subtypes contain seven immunoglobulin-like domains in the extracellular region and a tyrosine kinase domain in the intracellular region. VEGFR-1 and VEGFR-2 are expressed in ECs and hematopoietic stem cells $(47,49)$. VEGFR-1 is also expressed in monocytes and macrophages. By contrast, VEGFR-3 is only expressed in lymphatic ECs. The VEGF protein has 
a different affinity for each of the three VEGFR subtypes. VEGF-A is capable of activating VEGFR-1 and VEGFR-2; however, VEGFR-1 binds VEGF-A with an affinity 10-fold that for VEGFR-2. VEGF-VEGFR-2 signaling is crucial for vascular development and maintenance, whereas VEGFR-1 is an anti-angiogenic decoy receptor for VEGF and is required for normal vascular development $(49,50)$.

After an MI, the expression of VEGF is upregulated in the myocardium and the peripheral blood, promoting angiogenesis and improving cardiac function (51). Therefore, several studies have used experimental animal models to investigate whether increasing the amount of VEGF in myocardial tissue protects $\mathrm{CMs}$ and improves cardiac function. One example is the use of collagen-binding domain specific for myocardial extracellular matrix in animals with chronic infarction. In one of these studies, modified VEGF was injected into the myocardium adjacent to the infarct in pig hearts, which resulted in angiogenesis and subsequent formation of CMs in the infarcted area for up to 3 months (52). Similarly, other researchers have used nanoparticle technology to increase the amounts of VEGF in myocardial tissue, achieving similar results (53). As regard the treatment of preclinical MI, there have been many reports of successful promotion of angiogenesis in the infarcted myocardium after treatment with VEGF gene or protein. However, the responses to VEGF were found to be dose-dependent in clinical trials. Moreover, administration of large doses of recombinant VEGF protein has been found to result in various adverse effects $(54,55)$.

VEGF-A, a mitogen and survival factor characteristic of vascular ECs, is expressed in the epithelial cells of the terminal respiratory region in the fetal and postnatal lung (56) and it exerts a strong effect on pulmonary angiogenesis. Some clinical and basic studies have found that plasma VEGF concentrations and the expression of VEGF and VEGFR in lung tissue increase with hypoxia (55-58). In animal models, blocking VEGF-A receptors with the VEGF inhibitor Sugen 5416 induces PAH (59). Some studies have demonstrated that Sugen 5416 induces proliferation of blood secretory ECs and apoptosis of human microvascular pulmonary ECs by activating aromatic hydrocarbon receptors (AhRs) (60-62). Sugen 5416 has also been demonstrated to induce proliferation of human PASMCs by inducing nuclear translocation of AhR under hypoxic conditions (62). The findings mentioned above suggest that apoptosis of pulmonary microvascular ECs and translocation of AhR into the nuclei of human PASMCs lead to proliferation of pulmonary artery smooth muscle, which may be the pathological mechanism underlying the development of PAH.

VEGF165b is a specific subtype of VEGF-A with anti-angiogenic effects (63). VEGF165b reportedly contributes to the pathophysiology of PAH, particularly idiopathic PAH (64). VEGFR-2, a transmembrane tyrosine kinase receptor that is primarily expressed in the pulmonary endothelium, is the major receptor involved in VEGF-A angiogenesis $(65,66)$. Inhibition of VEGFR-2 reduces the density of blood vessels, inhibits formation of alveoli, and reduces the weight of the lungs of newborn rats compared with those of the control group. These pathological changes eventually lead to PAH $(67,68)$. In addition, recombinant human VEGF-A treatment and VEGFA gene therapy can restore pulmonary vascular growth and lung structure, and help protect lung function in rats $(69,70)$. It has been reported that the expression of VEGFR-2 is weak in patients with pulmonary bronchial dysplasia (71). There is some evidence indicating an important role of the VEGF-VEGFR-2 signaling axis in maintaining endothelial homeostasis. Recent studies have found that the activity of VEGFR-1 and VEGFR-2 is relatively balanced in ECs. Kivelä et al found that VEGFR-1-knockout ECs strongly express neuregulin-1 and heparin-binding epidermal growth factor via VEGFR-2-Notch signaling. Binding to erbB receptors on CMs results in induction of hypertrophy of CMs and cardiac angiogenesis (72). Neuroregulatory proteins (members of the epidermal growth factor family) are produced by endothelial and myocardial cells containing the receptor (erbB) of the ligand. Of note, neuroregulatory proteins from cardiac ECs can slow hypoxia-related death of $\mathrm{CM}_{\mathrm{S}}$ and reoxygenation through the paracrine effects of CMs (73). Taken together, these findings indicate that VEGF plays an important and unique role in the heart and lungs. On the one hand, VEGF affects angiogenesis and myocardial survival in infarcted myocardium $(52,53)$; on the other hand, VEGF acts on various complex pathophysiological mechanisms in ECs, particularly the balance of VEGFR-1 and VEGFR-2 in ECs (72). This determines its signal transduction direction, thereby affecting the function of ECs. Both VEGF and its splice variants and several complex signaling pathways play important roles in PAH, similarly to bone morphogenetic protein receptor type II (BMPR2). The interaction between BMPR2 and VEGF also requires attention. It has been reported that absence of BMPR2 can inhibit VEGF signaling (74). Additionally, as mentioned earlier, VEGF is also implicated in pulmonary hypertension and myocardial injury by activating NOX to generate ROS, which indicates the existence of a complex regulatory network between organs. Differences in the pathophysiological effects of VEGF between CMs and pulmonary vascular ECs require further investigations in diseases such as post-MI PAH (Fig. 4).

\section{Bone morphogenetic protein}

The pathogenesis of PAH usually involves abnormalities in the bone morphogenetic protein (BMP) pathway. BMP is a secreted protein of the transforming growth factor (TGF)- $\beta$ superfamily. A series of studies have documented that BMP signaling plays a key role in the cellular processes of proliferation, differentiation, and apoptosis in various tissues (75). In particular, it plays an important role in regulating cell pattern, differentiation, proliferation and apoptosis in the process of embryogenesis. BMP signaling is involved in promoting cell survival and proliferation in distal lung epithelial cells (76). Typical BMP signaling cascades can be divided into four subgroups as follows: BMP ligands, receptors, extracellular secretory antagonists and cell-reactive kinases. Over 20 BMP ligands have been identified to date. BMP-binding receptors are a group of transmembrane serine/threonine kinase receptors involved in type I (ALK2, ALK3 and ALK6) and type II (BMPR-II, ActR-IIa, and ActR-IIb) receptors (75). ALK1 is expressed on the surfaces of pulmonary vascular ECs, but not in PASMCs (77); ALK3 and ALK2 are expressed in both ECs and PASMCs (78); and BMPR-II is mainly expressed on the surface of pulmonary vascular ECs, but less strongly 


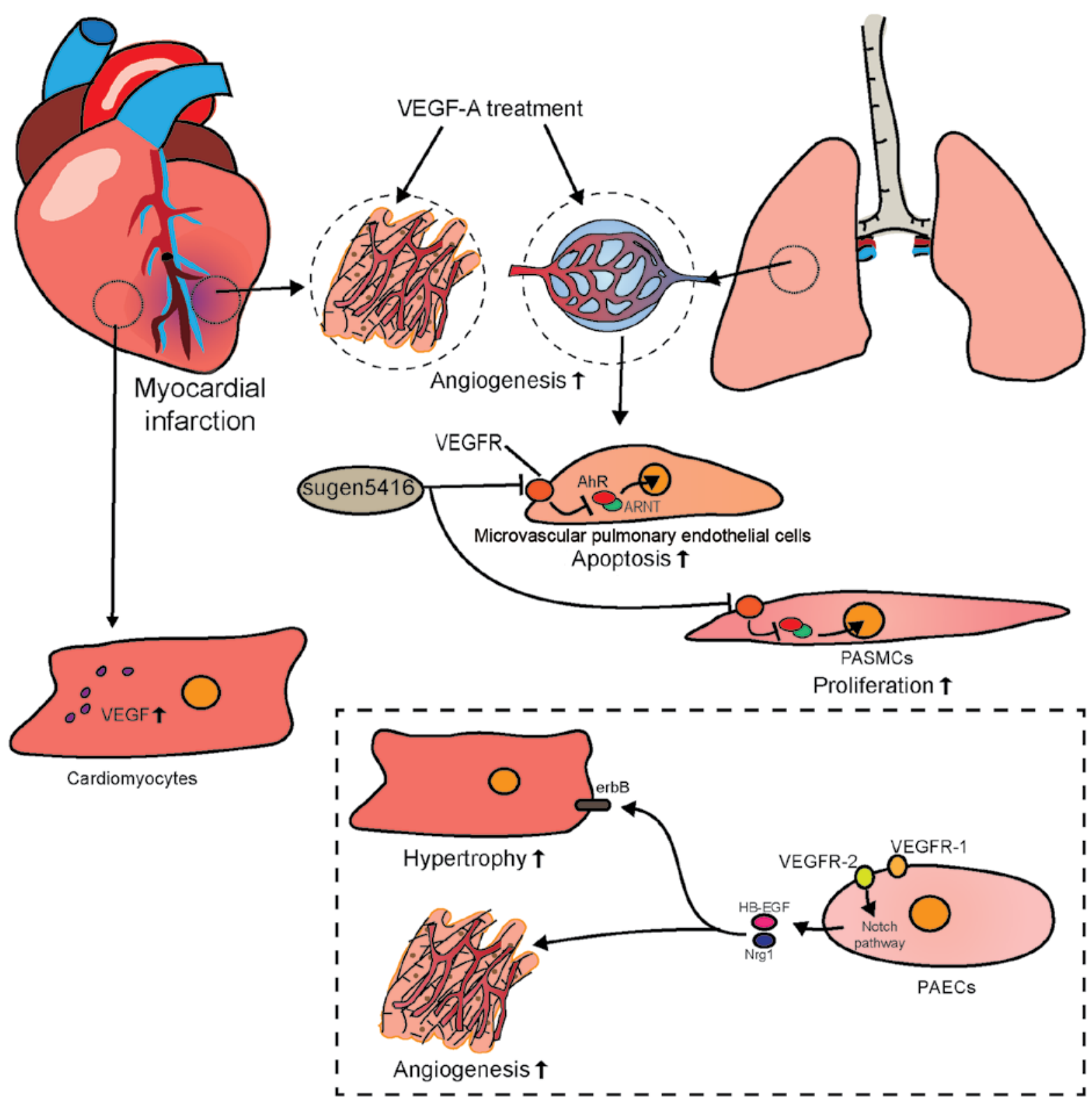

Figure 4. Role of VEGF in the crosstalk between the heart and lung. VEGF, vascular endothelial growth factor; VEGFR, VEGF receptor; PASMCs, pulmonary artery smooth muscle cells.

in smooth muscle and interstitial cells $(79,80)$. BMP ligands initiate signal transduction by binding to type II receptors. They then recruit type I receptors and activate a range of intracellular kinases, including classic Smad signals and various mitogen-activated protein kinases. These signaling pathways are known to be involved in regulating cell proliferation, differentiation, mitosis, cell survival and apoptosis (75). BMP antagonists are secreted proteins that compete with specific BMP ligands for binding and, thus, inhibit their signal transduction. The main members of this protein family are noggin, follistatin, gremlin 1, matrix gla protein, chordin, twisted gastrin 1, and Bmper (81). BMP antagonists can inhibit BMP signaling by chelation of BMP ligands in a range of different cell types.

The BMP signaling pathway is involved in the pathophysiology of various diseases in adults. For example, an imbalance of BMP activity is associated with osteoarthritis and rheumatoid arthritis (82). Mutations in components of the BMP pathway are also associated with human gastrointestinal and cardiovascular diseases, such as PAH (83). There is evidence that ligands that are closely associated with BMP2 and BMP4 can cause upregulation of oxidative stress and inflammatory pathways in lung and coronary ECs. In addition, upregulation of BMP4 mRNA reportedly occurs in the lung after exposure to a hypoxic environment (84).

Evidence from patients with PAH and multiple well-defined experimental PAH models suggests that dysfunction of pulmonary artery ECs (PAECs) causes increased vascular permeability and excessive proliferation of PASMCs, inducing perivascular inflammation (85). Reduction in the barrier function of PAECs and pulmonary vascular remodeling are characteristic pathological characteristics of PAH. Abnormal morphological changes in BMP ligands are also closely associated with the pathogenesis of PAH. Hypoxia-responsive transcription factor hypoxia-inducible factor (HIF)-1 $\alpha$ reportedly regulates BMP4 transcription by directly binding to the 
promoter region of the BMP4 gene and triggering BMP4 signaling (86). Han et al found that SMAD1 deficiency in endothelial or smooth muscle cells may render mice susceptible to PAH. This deficiency results in impairment of the balance between BMP4 and TGF- $\beta 1$-mediated signaling pathways, indicating BMP downstream mediators. SMAD1 is also crucial for PAH-related BMPR-II signaling (87). In hypoxic $\mathrm{PAH}$, high intracellular calcium concentrations play a key role in promoting contraction and proliferation of PASMCs. In PASMCs, hypoxia-triggered storage-operated calcium entry greatly promotes high intracellular calcium concentrations, which increase under hypoxic conditions. Hypoxia induces stabilization of HIF-1 $\alpha$ (86). By transcriptionally activating BMP4 expression, BMP4 induces stronger expression of TORC1 and TRPC6. This triggers storage-operated calcium entry, which results in increased proliferation and migration of PASMCs (88). As regards BMPR-II-related EC function, Yang et al further demonstrated that adenovirus overexpression of BMPR-II mutant (kinase-deficient mutation, D485G) in PAECs not only promotes their apoptosis, but also induces secretion of growth factors (89). These findings suggest that abnormalities in BMP signaling lead to increased EC dysfunction and vascular permeability, and promote vascular smooth muscle cell proliferation, further contributing to the development and exacerbation of PAH. Recent research on the treatment of PAH has shown that inhibiting BMPs by increasing the expression of BMPR-II and inhibiting BMP ligand antagonists can ameliorate this condition.

Recent studies have demonstrated that expression of BMP-2 increases, whereas that of BMP-4 decreases when CMs are mechanically stimulated, as occurs when BMP2 and BMP2 autocrine/paracrine factors regulate the mechanical conduction and mechanical stretch of CMs (90). There is evidence that BMP-mediated transient suppression of signal transduction can promote differentiation of CMs, and that BMP2 increases the contractility of CMs. Therefore, previous studies have investigated the potential of BMP for treating heart disease. For example, administration of recombinant BMP2 has been shown to reduce infarct size after MI in mice, even for mature CMs (91). Another study demonstrated that BMP2 treatment can induce c-kit cardiac stem cells to differentiate into functional CMs; thus, BMP2 can promote repair of infarcted myocardium, thereby improving cardiac function (92). Activation of BMP4 signaling promotes apoptosis after MI induced by I/R injury. Additionally, in vivo treatment with noggin reduces infarct size and inhibits pre-apoptotic signals while inhibiting Smad1 phosphorylation and JNK activation (91). The BMP antagonist gremlin 2 (Grem2) is required for early cardiac development and CM differentiation. It has been found that the adult heart strongly but transiently induces formation of Grem 2 in the inflammatory phase of myocardial tissue repair following experimental induction of MI. In wild-type mice, intraperitoneal injection of Grem 2 protein can reduce post-MI inflammation. It has been found that BMP2 interacts with TNF- $\alpha$ to induce expression of proinflammatory proteins and promote leukocyte adhesion in ECs. However, Grem2 specifically inhibits BMP2 and has been shown to control the extent of inflammatory cell infiltration by inhibiting classical BMP signaling (93).
The findings mentioned above indicate that BMP signaling is important for the normal development of the heart and pulmonary vessels, which suggests that there is BMP signal crosstalk between the heart and the pulmonary vessels, for which, however, there is currently no direct evidence. For example, the endogenous BMP antagonist Grem2, which is induced by MI, can alleviate inflammatory responses caused by MI. However, whether it can affect the BMP signaling of pulmonary vascular cells deserves further investigation. The role of BMP signaling in the early stages of post-MI PAH also warrants further investigation. Additionally, BMP2 exerts a positive effect on both CMs and pulmonary vascular cells, whereas BMP4 has a negative impact. Thus, when developing BMP-related treatments, signaling pathway crosstalk between multiple organs must be taken into consideration to ensure safety. However, the relevance of such crosstalk has not yet been determined (Fig. 5).

\section{Adiponectin}

Adiponectin, an insulin-sensitizing hormone secreted by adipocytes that reduces endoplasmic reticulum stress and ROS in ECs (94), plays an important role in the resistance of these cells to oxidative stress. It has been reported that plasma adiponectin concentrations are significantly lower in patients with cardiovascular disease compared with those in healthy individuals. Of note, cardiac cells can also secrete adiponectin $(95,96)$. Upregulation of the expression of adiponectin in microvascular ECs and CMs of diabetic mice slows ischemic injury of the myocardium and improves cardiac function. Additionally, the adiponectin gene is regulated by HIF-1 (97). Experimental studies have demonstrated that HIF-1 protects the heart from acute I/R injury through transcriptional activation of cardiac protective genes (such as erythropoietin, heme oxygenase-1 and inducible NO synthase) (95). Interestingly, HIF-1 $\alpha$ is currently considered to play a negative role in the BMP signaling pathway described earlier in this article. Thus, the research on the role of adiponectin in pulmonary vessels has been insufficient thus far. However, the abovementioned evidence provides new clues regarding the role of adiponectin in the heart and lungs and the pathological mechanism underlying post-MI PAH (Fig. 6).

\section{Conclusions}

There is currently sufficient evidence indicating that signaling pathways and action molecules are shared between the heart and lungs, and that these molecules are expressed to different degrees in the cardiac tissue and pulmonary vessels and play different roles in the circulation of the heart and lungs. The origins and development of diseases are not limited to the affected organ; rather, internal imbalance and dysregulation between organs usually underlies disease development. Research on the interaction between the heart and lungs is currently focused mainly on the effect of hypoxic PAH on the heart. The main therapeutic targets of PAH are ET-1, NO and prostacyclin; however, there are also RAS, VEGF, BMP, as well as other signaling pathways. The specific regulatory mechanisms of these signaling pathways remain unclear. Existing treatment protocols also have their limitations. 


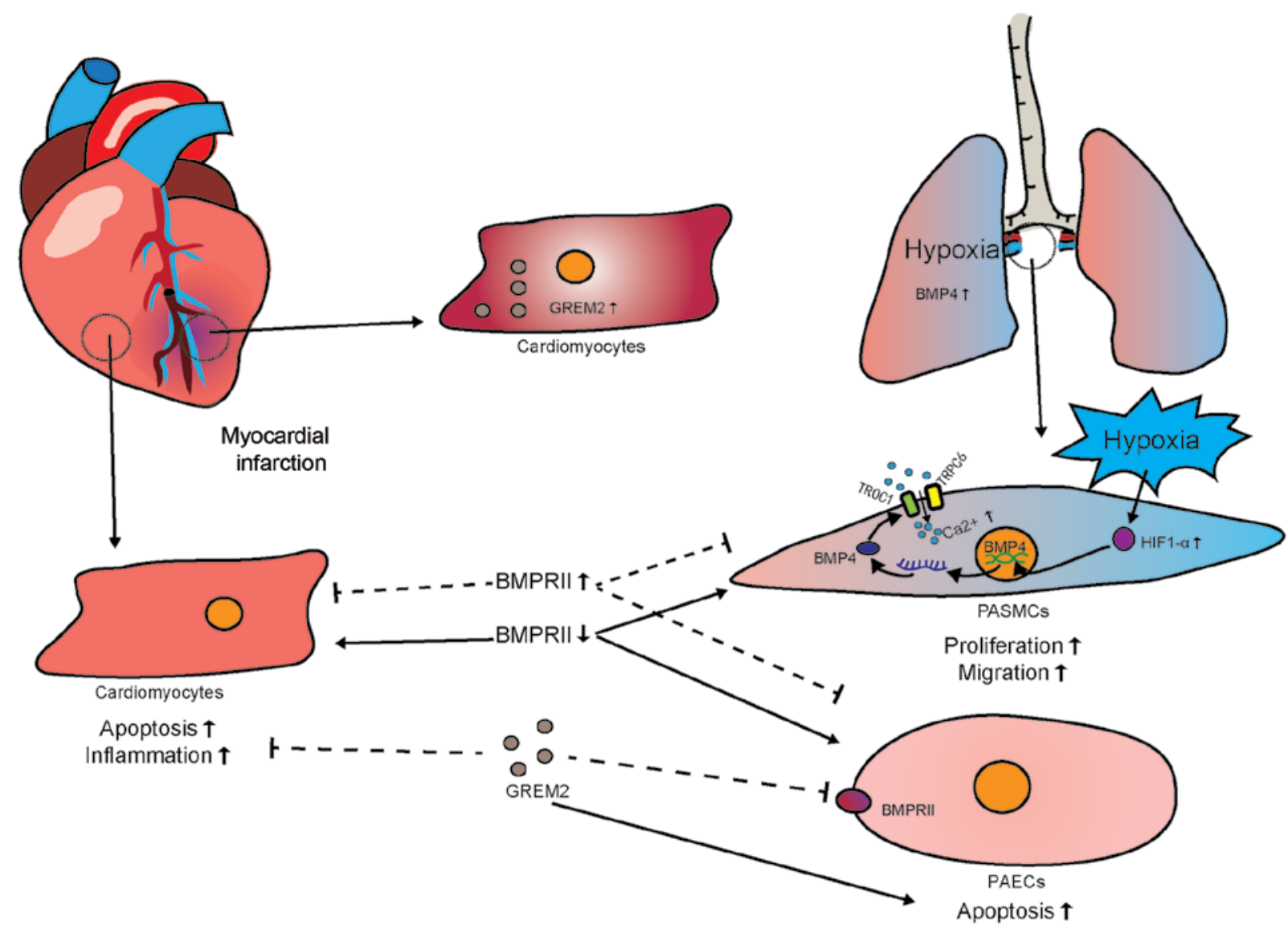

Figure 5. Role of BMP signals in the crosstalk between the heart and lung. BMP, bone morphogenetic protein; PASMCs, pulmonary artery smooth muscle cells; PAECs, pulmonary artery endothelial cells; HIF, hypoxa-inducible factor.
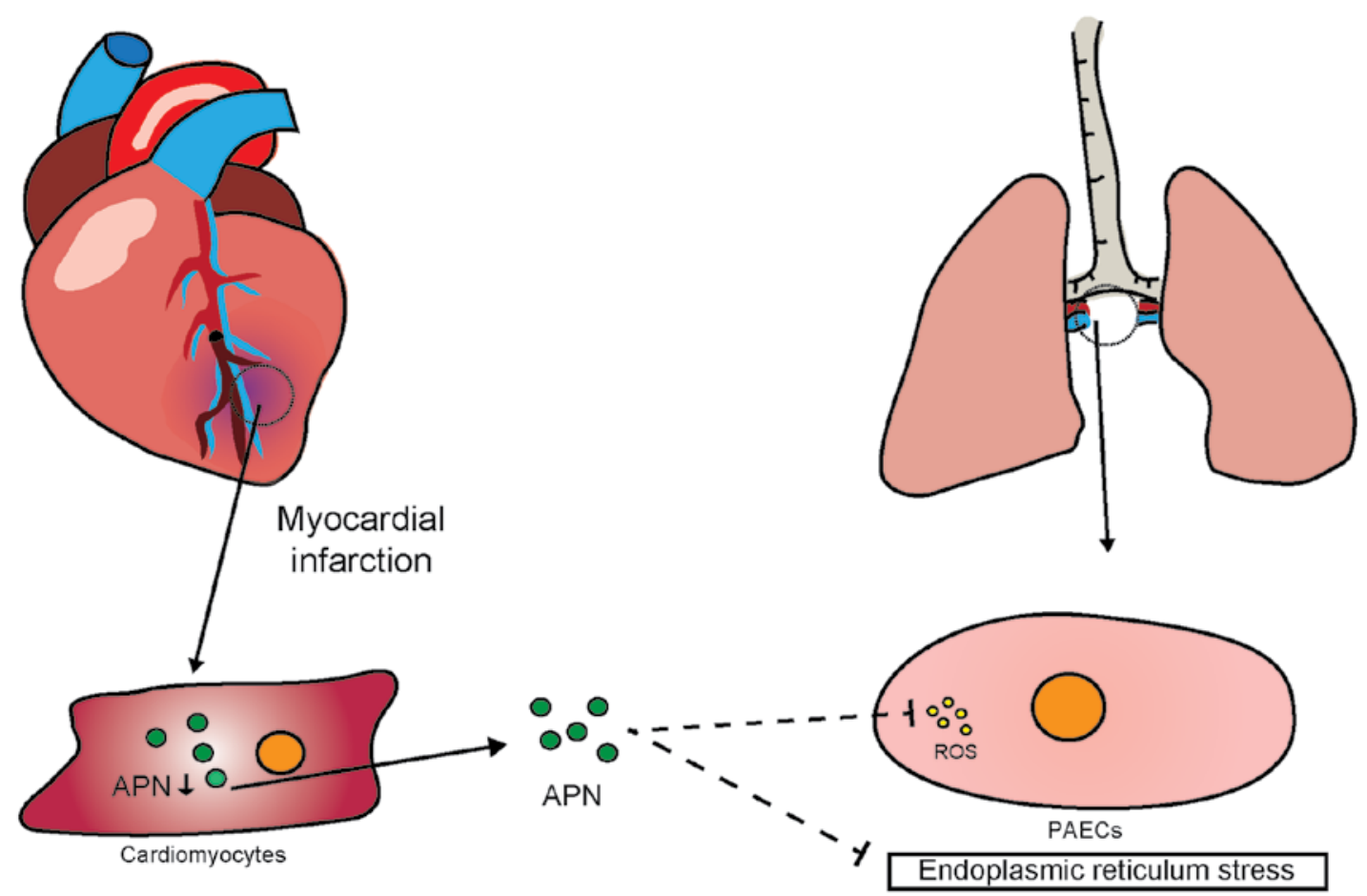

Figure 6. Role of APN in the crosstalk between the heart and lung. APN, adiponectin; PAECs, pulmonary artery endothelial cells; ROS, reactive oxygen species.

Further studies are required to elucidate pathogenetic and pathophysiological factors, in order to enable diagnosis of these diseases by measuring the levels of identified pathology-related molecules, and reduction of their incidence by implementing 
effective preventive drug interventions at an early stage of the disease. This may both improve the effectiveness of treatment and greatly reduce the incidence of PAH caused by MI. The current challenge is to improve the understanding of the pathogenesis of post-MI PAH, including the mechanisms through which signal regulators affect PAH and the complexity of cardiopulmonary physiological characteristics. This would improve the efficacy of prevention and treatment of this condition. We believe that elucidating the mechanisms underlying cardiopulmonary interaction would not only improve our understanding of the pathological process of PAH post-MI, but may also provide a new basis and identify new therapeutic targets for the prevention and treatment of PAH.

\section{Acknowledgements}

Not applicable.

\section{Funding}

The present study was supported by grants from the National Natural Science Foundation of China (nos. 81970056, 81700269 and 81741129), the Southern Marine Science and Engineering Guangdong Laboratory Zhanjiang (no. ZJW-2019-07), the Natural Science Foundation of Guangdong Province (no. 2019A1515011925), and the Science and Technology Plan Project of Zhanjiang (no. 2019A01002).

\section{Availability of data and materials}

Not applicable.

\section{Authors' contributions}

WL, SH and HL contributed to the conception of the study, WY, HG, JX, SC, XS and YH performed the literature search and wrote the manuscript. WY prepared the figures. All the authors have read and approved the final manuscript.

\section{Ethics approval and consent to participate}

Not applicable.

\section{Patient consent for publication}

Not applicable.

\section{Competing interests}

The authors declare that they have no competing interests.

\section{References}

1. Breitling S, Ravindran K, Goldenberg NM and Kuebler WM: The pathophysiology of pulmonary hypertension in left heart disease. Am J Physiol Lung Cell Mol Physiol 309: L924-L941, 2015.

2. Lundgren $\mathrm{J}$ and Rådegran G: Pathophysiology and potential treatments of pulmonary hypertension due to systolic left heart failure. Acta Physiol (Oxf) 211: 314-333, 2014.

3. Raiesdana A and Loscalzo J: Pulmonary arterial hypertension. Ann Med 38: 95-110, 2006.
4. van Duin RWB, Houweling B, Uitterdijk A, Duncker DJ and Merkus D: Pulmonary vasodilation by phosphodiesterase 5 inhibition is enhanced and nitric oxide independent in early pulmonary hypertension after myocardial infarction. Am J Physiol Heart Circ Physiol 314: H170-H179, 2018.

5. Hunt JM, Bethea B, Liu X, Gandjeva A, Mammen PP, Stacher E, Gandjeva MR, Parish E, Perez M, Smith L, et al: Pulmonary veins in the normal lung and pulmonary hypertension due to left heart disease. Am J Physiol Lung Cell Mol Physiol 305: L725-L736, 2013.

6. Fujimoto Y, Urashima T, Kawachi F, Akaike T, Kusakari Y, Ida $\mathrm{H}$ and Minamisawa S: Pulmonary hypertension due to left heart disease causes intrapulmonary venous arterialization in rats. J Thorac Cardiovasc Surg 154: 1742-1753.e8, 2017.

7. Ghio S, Gavazzi A, Campana C, Inserra C, Klersy C, Sebastiani R, Arbustini E, Recusani F and Tavazzi L: Independent and additive prognostic value of right ventricular systolic function and pulmonary artery pressure in patients with chronic heart failure. J Am Coll Cardiol 37: 183-188, 2001.

8. Lipworth BJ and Dagg KD: Vasoconstrictor effects of angiotensin II on the pulmonary vascular bed. Chest 105: 1360-1364, 1994.

9. Morrell NW, Upton PD, Higham MA, Yacoub MH, Polak JM and Wharton J: Angiotensin II stimulates proliferation of human pulmonary artery smooth muscle cells via the AT1 receptor. Chest 114 (1 Suppl): 90S-91S, 1998.

10. Houweling B, Merkus D, Sorop O, Boomsma F and Duncker DJ: Role of endothelin receptor activation in secondary pulmonary hypertension in awake swine after myocardial infarction. J Physiol 574: 615-626, 2006

11. de Man FS, Tu L, Handoko ML, Rain S, Ruiter G, François C, Schalij I, Dorfmüller P, Simonneau G, Fadel E, et al: Dysregulated renin-angiotensin-aldosterone system contributes to pulmonary arterial hypertension. Am J Respir Crit Care Med 186: 780-789, 2012.

12. Bruce E, Shenoy V, Rathinasabapathy A, Espejo A, Horowitz A, Oswalt A, Francis J, Nair A, Unger T, Raizada MK, et al: Selective activation of angiotensin AT2 receptors attenuates progression of pulmonary hypertension and inhibits cardiopulmonary fibrosis. Br J Pharmacol 172: 2219-2231, 2015.

13. Strawn WB, Richmond RS, Ann Tallant E, Gallagher PE and Ferrario CM: Renin-angiotensin system expression in rat bone marrow haematopoietic and stromal cells. Br J Haematol 126: 120-126, 2004.

14. Liu C, Fan Y, Zhou L, Zhu HY, Song YC, Hu L, Wang Y and Li QP: Pretreatment of mesenchymal stem cells with angiotensin II enhances paracrine effects, angiogenesis, gap junction formation and therapeutic efficacy for myocardial infarction. Int $\mathbf{J}$ Cardiol 188: 22-32, 2015.

15. Mendoza-Torres E, Oyarzún A, Mondaca-Ruff D, Azocar A, Castro PF, Jalil JE, Chiong M, Lavandero S and Ocaranza MP: ACE2 and vasoactive peptides: Novel players in cardiovascular/renal remodeling and hypertension. Ther Adv Cardiovasc Dis 9: 217-237, 2015.

16. Santos RA, Ferreira AJ, Verano-Braga $T$ and Bader M: Angiotensin-converting enzyme 2, angiotensin-(1-7) and Mas: New players of the renin-angiotensin system. J Endocrinol 216: R1-R17, 2013.

17. Morrell NW, Atochina EN, Morris KG, Danilov SM and Stenmark KR: Angiotensin converting enzyme expression is increased in small pulmonary arteries of rats with hypoxia-induced pulmonary hypertension. J Clin Invest 96: 1823-1833, 1995.

18. Mann S, Bajulaiye A, Sturgeon K, Sabri A, Muthukumaran G and Libonati JR: Effects of acute angiotensin II on ischemia reperfusion injury following myocardial infarction. J Renin Angiotensin Aldosterone Syst 16: 13-22, 2015.

19. Xu J, Carretero OA, Lin CX, Cavasin MA, Shesely EG, Yang JJ, Reudelhuber TL and Yang XP: Role of cardiac overexpression of ANG II in the regulation of cardiac function and remodeling postmyocardial infarction. Am J Physiol Heart Circ Physiol 293: H1900-H1907, 2007.

20. Shenoy V, Qi Y, Katovich MJ and Raizada MK: ACE2, a promising therapeutic target for pulmonary hypertension. Curr Opin Pharmacol 11: 150-155, 2011.

21. Lassègue B, San Martín A and Griendling KK: Biochemistry, physiology, and pathophysiology of NADPH oxidases in the cardiovascular system. Circ Res 110: 1364-1390, 2012.

22. Zhu X and Zuo L: Characterization of oxygen radical formation mechanism at early cardiac ischemia. Cell Death Dis 4: e787, 2013. 
23. Shiomi T, Tsutsui H, Matsusaka H, Murakami K, Hayashidani S, Ikeuchi M, Wen J, Kubota T, Utsumi $\mathrm{H}$ and Takeshita A: Overexpression of glutathione peroxidase prevents left ventricular remodeling and failure after myocardial infarction in mice. Circulation 109: 544-549, 2004.

24. Bowers R, Cool C, Murphy RC, Tuder RM, Hopken MW, Flores SC and Voelkel NF: Oxidative stress in severe pulmonary hypertension. Am J Respir Crit Care Med 169: 764-769, 2004.

25. Wang X, Shults NV and Suzuki YJ: Oxidative profiling of the failing right heart in rats with pulmonary hypertension. PLoS One 12: e0176887, 2017.

26. Suresh K and Shimoda LA: Endothelial cell reactive oxygen species and $\mathrm{Ca}^{2+}$ signaling in pulmonary hypertension. Adv Exp Med Biol 967: 299-314, 2017.

27. Guo D, Gu J, Jiang H, Ahmed A, Zhang Z and Gu Y: Inhibition of pyruvate kinase $\mathrm{M} 2$ by reactive oxygen species contributes to the development of pulmonary arterial hypertension. J Mol Cell Cardiol 91: 179-187, 2016.

28. Jaitovich A and Jourd'heuil D: A brief overview of nitric oxide and reactive oxygen species signaling in hypoxia-induced pulmonary hypertension. Adv Exp Med Biol 967: 71-81, 2017.

29. Shahzad S, Hasan A, Faizy AF, Mateen S, Fatima N and Moin S Elevated DNA damage, oxidative stress, and impaired response defense system inflicted in patients with myocardial infarction. Clin Appl Thromb Hemost 24: 780-789, 2018.

30. Freund-Michel V, Guibert C, Dubois M, Courtois A, Marthan R, Savineau JP and Muller B: Reactive oxygen species as therapeutic targets in pulmonary hypertension. Ther Adv Respir Dis 7: 175-200, 2013.

31. Kedzierski RM and Yanagisawa M: Endothelin system: The double-edged sword in health and disease. Annu Rev Pharmacol Toxicol 41: 851-876, 2001.

32. Madonna R, Cocco N and De Caterina R: Pathways and drugs in pulmonary arterial hypertension-focus on the role of endothelin receptor antagonists. Cardiovasc Drugs Ther 29: 469-479, 2015.

33. Sato K, Oka M, Hasunuma K, Ohnishi M, Sato K and Kira S: Effects of separate and combined ETA and ETB blockade on ET-1-induced constriction in perfused rat lungs. Am J Physiol 269: L668-L672, 1995.

34. Taguchi K and Hattori Y: Unlooked-for significance of cardiac versus vascular effects of endothelin-1 in the pathophysiology of pulmonary arterial hypertension. Circ Res 112: 227-229, 2013.

35. Van Hung T, Emoto N, Vignon-Zellweger N, Nakayama K, Yagi K, Suzuki Y and Hirata K: Inhibition of vascular endothelial growth factor receptor under hypoxia causes severe human-like pulmonary arterial hypertension in mice: Potential roles of interleukin-6 and endothelin. Life Sci 118: 313-328, 2014.

36. Merkus D, Houweling B, Mirza A, Boomsma F, van den Meiracker AH and Duncker DJ: Contribution of endothelin and its receptors to the regulation of vascular tone during exercise is different in the systemic, coronary and pulmonary circulation. Cardiovasc Res 59: 745-754, 2003

37. Galiè N, Olschewski H, Oudiz RJ, Torres F, Frost A, Ghofrani HA Badesch DB, McGoon MD, McLaughlin VV, Roecker EB, et al: Ambrisentan for the treatment of pulmonary arterial hypertension: Results of the ambrisentan in pulmonary arterial hypertension, randomized, double-blind, placebo-controlled, multicenter, efficacy (ARIES) study 1 and 2. Circulation 117: 3010-3019, 2008

38. Oudiz RJ, Galiè N, Olschewski H, Torres F, Frost A, Ghofrani HA Badesch DB, McGoon MD, McLaughlin VV, Roecker EB, et al: Long-term ambrisentan therapy for the treatment of pulmonary arterial hypertension. J Am Coll Cardiol 54: 1971-1981, 2009.

39. Tanaka Y, Hino M and Gemma A: Potential benefit of bosentan therapy in borderline or less severe pulmonary hypertension secondary to idiopathic pulmonary fibrosis-an interim analysis of results from a prospective, single-center, randomized, parallel-group study. BMC Pulm Med 17: 200, 2017.

40. Skovsted GF, Kruse LS, Berchtold LA, Grell AS, Warfvinge K and Edvinsson L: Myocardial ischemia-reperfusion enhances transcriptional expression of endothelin-1 and vasoconstrictor ETB receptors via the protein kinase MEK-ERK1/2 signaling pathway in rat. PLoS One 12: e0174119, 2017.

41. van Duin RWB, Stam K, Cai Z, Uitterdijk A, Garcia-Alvarez A, Ibanez B, Danser AHJ, Reiss IKM, Duncker DJ and Merkus D: Transition from post-capillary pulmonary hypertension to combined pre- and post-capillary pulmonary hypertension in swine: A key role for endothelin. J Physiol 597: 1157-1173, 2019.
42. Merkus D, Houweling B, de Beer VJ, Everon Z and Duncker DJ: Alterations in endothelial control of the pulmonary circulation in exercising swine with secondary pulmonary hypertension after myocardial infarction. J Physiol 580: 907-923, 2007.

43. Satwiko MG, Ikeda K, Nakayama K, Yagi K, Hocher B, Hirata K and Emoto N: Targeted activation of endothelin-1 exacerbates hypoxia-induced pulmonary hypertension. Biochem Biophys Res Commun 465: 356-362, 2015.

44. Hocher B, Thöne-Reineke C, Rohmeiss P, Schmager F, Slowinski T, Burst V, Siegmund F, Quertermous T, Bauer C, Neumayer HH, et al: Endothelin-1 transgenic mice develop glomerulosclerosis, interstitial fibrosis, and renal cysts but not hypertension. J Clin Invest 99: 1380-1389, 1997.

45. Giaid A, Yanagisawa M, Langleben D, Michel RP, Levy R, Shennib H, Kimura S, Masaki T, Duguid WP and Stewart DJ: Expression of endothelin-1 in the lungs of patients with pulmonary hypertension. N Engl J Med 328: 1732-1739, 1993.

46. Wackenfors A, Emilson M, Ingemansson R, Hortobagyi T, Szok D, Tajti J, Vecsei L, Edvinsson L and Malmsjö M: Ischemic heart disease induces upregulation of endothelin receptor mRNA in human coronary arteries. Eur J Pharmacol 484: 103-109, 2004.

47. Tammela T, Enholm B, Alitalo K and Paavonen K: The biology of vascular endothelial growth factors. Cardiovasc Res 65 $550-563,2005$.

48. Kikuchi R, Stevens M, Harada K, Oltean S and Murohara T: Anti-angiogenic isoform of vascular endothelial growth factor-A in cardiovascular and renal disease. Adv Clin Chem 88: 1-33, 2019.

49. Ferrara N, Gerber HP and LeCouter J: The biology of VEGF and its receptors. Nat Med 9: 669-676, 2003.

50. Ruhrberg C, Gerhardt H, Golding M, Watson R, Ioannidou S, Fujisawa H, Betsholtz C and Shima DT: Spatially restricted patterning cues provided by heparin-binding VEGF-A control blood vessel branching morphogenesis. Genes Dev 16: 2684-2698, 2002.

51. Yang Y, Shi C, Hou X, Zhao Y, Chen B, Tan B, Deng Z, Li Q, Liu J, Xiao Z, et al: Modified VEGF targets the ischemic myocardium and promotes functional recovery after myocardial infarction. J Control Release 213: 27-35, 2015.

52. Shi C, Zhao Y, Yang Y, Chen C, Hou X, Shao J, Yao H, Li Q, $\mathrm{Xia} Y$ and Dai J: Collagen-binding VEGF targeting the cardiac extracellular matrix promotes recovery in porcine chronic myocardial infarction. Biomater Sci 6: 356-363, 2018.

53. Oduk Y, Zhu W, Kannappan R, Zhao M, Borovjagin AV, Oparil S and Zhang JJ: VEGF nanoparticles repair the heart after myocardial infarction. Am J Physiol Heart Circ Physiol 314: H278-H284, 2018.

54. Henry TD, Annex BH, McKendall GR, Azrin MA, Lopez JJ, Giordano FJ, Shah PK, Willerson JT, Benza RL, Berman DS, et al: The VIVA trial: Vascular endothelial growth factor in ischemia for vascular angiogenesis. Circulation 107: 1359-1365, 2003.

55. Sato K, Wu T, Laham RJ, Johnson RB, Douglas P, Li J, Sellke FW, Bunting S, Simons M and Post MJ: Efficacy of intracoronary or intravenous VEGF165 in a pig model of chronic myocardial ischemia. J Am Coll Cardiol 37: 616-623, 2001.

56. Bhatt AJ, Amin SB, Chess PR, Watkins RH and Maniscalco WM: Expression of vascular endothelial growth factor and Flk-1 in developing and glucocorticoid-treated mouse lung. Pediatr Res 47: 606-613, 2000.

57. Eddahibi S, Humbert M, Sediame S, Chouaid C, Partovian C, Maître B, Teiger E, Rideau D, Simonneau G, Sitbon O and Adnot S: Imbalance between platelet vascular endothelial growth factor and platelet-derived growth factor in pulmonary hypertension. Effect of prostacyclin therapy. Am J Respir Crit Care Med 162: 1493-1499, 2000.

58. Tuder RM, Flook BE and Voelkel NF: Increased gene expression for VEGF and the VEGF receptors KDR/Flk and Flt in lungs exposed to acute or to chronic hypoxia. Modulation of gene expression by nitric oxide. J Clin Invest 95: 1798-1807, 1995.

59. Al-Husseini A, Kraskauskas D, Mezzaroma E, Nordio A, Farkas D, Drake JI, Abbate A, Felty Q and Voelkel NF: Vascular endothelial growth factor receptor 3 signaling contributes to angioobliterative pulmonary hypertension. Pulm Circ 5: 101-116, 2015.

60. Taraseviciene-Stewart L, Kasahara Y, Alger L, Hirth P, Mc Mahon G, Waltenberger J, Voelkel NF and Tuder RM: Inhibition of the VEGF receptor 2 combined with chronic hypoxia causes cell death-dependent pulmonary endothelial cell proliferation and severe pulmonary hypertension. FASEB J 15: 427-438, 2001. 
61. Nicolls MR, Mizuno S, Taraseviciene-Stewart L, Farkas L, Drake JI, Al Husseini A, Gomez-Arroyo JG, Voelkel NF and Bogaard HJ: New models of pulmonary hypertension based on VEGF receptor blockade-induced endothelial cell apoptosis Pulm Circ 2: 434-442, 2012.

62. Dean A, Gregorc T, Docherty CK, Harvey KY, Nilsen M, Morrell NW and MacLean MR: Role of the Aryl hydrocarbon receptor in sugen 5416-induced experimental pulmonary hypertension. Am J Respir Cell Mol Biol 58: 320-330, 2018.

63. Bates DO, Cui TG, Doughty JM, Winkler M, Sugiono M, Shields JD, Peat D, Gillatt D and Harper SJ: VEGF165b, an inhibitory splice variant of vascular endothelial growth factor, is down-regulated in renal cell carcinoma. Cancer Res 62 : 4123-4131, 2002

64. Suzuki S, Yoshihisa A, Yokokawa T, Misaka T, Sakamoto N, Sugimoto K, Yamaki T, Kunii H, Nakazato K, Saitoh SI and Takeishi Y: Association between levels of anti-angiogenic isoform of vascular endothelial growth factor A and pulmonary hypertension. Int J Cardiol 222: 416-420, 2016.

65. Olsson AK, Dimberg A, Kreuger J and Claesson-Welsh L: VEGF receptor signaling-in control of vascular function. Nat Rev Mol Cell Biol 7: 359-371, 2006.

66. Yancopoulos GD, Davis S, Gale NW, Rudge JS, Wiegand SJ and Holash J: Vascular-specific growth factors and blood vessel formation. Nature 407: 242-248, 2000.

67. Jakkula M, Le Cras TD, Gebb S, Hirth KP, Tuder RM, Voelkel NF and Abman SH: Inhibition of angiogenesis decreases alveolarization in the developing rat lung. Am J Physiol Lung Cell Mol Physiol 279: L600-L607, 2000.

68. Le Cras TD, Markham NE, Tuder RM, Voelkel NF and Abman SH: Treatment of newborn rats with a VEGF receptor inhibitor causes pulmonary hypertension and abnormal lung structure. Am J Physiol Lung Cell Mol Physiol 283: L555-L562, 2002.

69. Kunig AM, Balasubramaniam V, Markham NE, Morgan D, Montgomery G, Grover TR and Abman SH: Recombinant human VEGF treatment enhances alveolarization after hyperoxic lung injury in neonatal rats. Am J Physiol Lung Cell Mol Physiol 289: L529-L535, 2005

70. Thébaud B, Ladha F, Michelakis ED, Sawicka M, Thurston G Eaton F, Hashimoto K, Harry G, Haromy A, Korbutt G and Archer SL: Vascular endothelial growth factor gene therapy increases survival, promotes lung angiogenesis, and prevents alveolar damage in hyperoxia-induced lung injury: Evidence that angiogenesis participates in alveolarization. Circulation 112 2477-2486, 2005.

71. Mahlman M, Huusko JM, Karjalainen MK, Kaukola T, Marttila R, Ojaniemi M, Haataja R, Lavoie PM, Rämet M and Hallman M; Gen-BPD Study Group: Genes encoding vascular endothelial growth factor A (VEGF-A) and VEGF receptor 2 (VEGFR-2) and risk for bronchopulmonary dysplasia. Neonatology 108: 53-59, 2015.

72. Kivelä R, Hemanthakumar KA, Vaparanta K, Robciuc M, Izumiya Y, Kidoya $\mathrm{H}$, Takakura N, Peng X, Sawyer DB, Elenius $\mathrm{K}$, et al: Endothelial cells regulate physiological cardiomyocyte growth via VEGFR2-mediated paracrine signaling. Circulation 139: 2570-2584, 2019.

73. Hedhli N, Huang Q, Kalinowski A, Palmeri M, Hu X, Russell RR and Russell KS: Endothelium-derived neuregulin protects the heart against ischemic injury. Circulation 123: 2254-2262, 2011.

74. Nagashima T, Li Q, Clementi C, Lydon JP, DeMayo FJ and Matzuk MM: BMPR2 is required for postimplantation uterine function and pregnancy maintenance. J Clin Invest 123 2539-2550, 2013

75. Morrell NW, Bloch DB, ten Dijke P, Goumans MJ, Hata A, Smith J, Yu PB and Bloch KD: Targeting BMP signalling in cardiovascular disease and anaemia. Nat Rev Cardiol 13: 106-120, 2016.

76. Eblaghie MC, Reedy M, Oliver T, Mishina Y and Hogan BL: Evidence that autocrine signaling through Bmprla regulates the proliferation, survival and morphogenetic behavior of distal lung epithelial cells. Dev Biol 291: 67-82, 2006.

77. Trembath RC, Thomson JR, Machado RD, Morgan NV, Atkinson C, Winship I, Simonneau G, Galie N, Loyd JE, Humbert M, et al: Clinical and molecular genetic features of pulmonary hypertension in patients with hereditary hemorrhagic telangiectasia. N Engl J Med 345: 325-334, 2001

78. Upton PD, Long L, Trembath RC and Morrell NW: Functional characterization of bone morphogenetic protein binding sites and Smad1/5 activation in human vascular cells. Mol Pharmacol 73 539-552, 2008
79. Atkinson C, Stewart S, Upton PD, Machado R, Thomson JR, Trembath RC and Morrell NW: Primary pulmonary hypertension is associated with reduced pulmonary vascular expression of type II bone morphogenetic protein receptor. Circulation 105 $1672-1678,2002$.

80. Southwood M, Jeffery TK, Yang X, Upton PD, Hall SM, Atkinson C, Haworth SG, Stewart S, Reynolds PN, Long L, et al: Regulation of bone morphogenetic protein signalling in human pulmonary vascular development. J Pathol 214: 85-95, 2008.

81. Brazil DP, Church RH, Surae S, Godson C and Martin F: BMP signalling: Agony and antagony in the family. Trends Cell Biol 25: 249-264, 2015.

82. Lories RJ and Luyten FP: Bone morphogenetic protein signaling in joint homeostasis and disease. Cytokine Growth Factor Rev 16: 287-298, 2005.

83. Deng Z, Morse JH, Slager SL, Cuervo N, Moore KJ, Venetos G, Kalachikov S, Cayanis E, Fischer SG, Barst RJ, et al: Familial primary pulmonary hypertension (gene PPH1) is caused by mutations in the bone morphogenetic protein receptor-II gene. Am J Hum Genet 67: 737-744, 2000

84. Frank DB, Abtahi A, Yamaguchi DJ, Manning S, Shyr Y, Pozzi A, Baldwin HS, Johnson JE and de Caestecker MP: Bone morphogenetic protein 4 promotes pulmonary vascular remodeling in hypoxic pulmonary hypertension. Circ Res 97: 496-504, 2005.

85. Sylvester JT, Shimoda LA, Aaronson PI and Ward JP: Hypoxic pulmonary vasoconstriction. Physiol Rev 92: 367-520, 2012.

86. Wang J, Fu X, Yang K, Jiang Q, Chen Y, Jia J, Duan X, Wang EW, He J, Ran P, et al: Hypoxia inducible factor-1-dependent up-regulation of BMP4 mediates hypoxia-induced increase of TRPC expression in PASMCs. Cardiovasc Res 107: 108-118, 2015.

87. Han C, Hong KH, Kim YH, Kim MJ, Song C, Kim MJ, Kim SJ, Raizada MK and Oh SP: SMAD1 deficiency in either endothelial or smooth muscle cells can predispose mice to pulmonary hypertension. Hypertension 61: 1044-1052, 2013.

88. Li X, Lu W, Fu X, Zhang Y, Yang K, Zhong N, Ran P and Wang J: BMP4 increases canonical transient receptor potential protein expression by activating p38 MAPK and ERK1/2 signaling pathways in pulmonary arterial smooth muscle cells. Am J Respir Cell Mol Biol 49: 212-220, 2013.

89. Yang X, Long L, Reynolds PN and Morrell NW: Expression of mutant BMPR-II in pulmonary endothelial cells promotes apoptosis and a release of factors that stimulate proliferation of pulmonary arterial smooth muscle cells. Pulm Circ 1: 103-110, 2011.

90. Tokola H, Rysä J, Pikkarainen S, Hautala N, Leskinen H, Kerkelä R, Ilves M, Aro J, Vuolteenaho O, Ritvos $\mathrm{O}$ and Ruskoaho H: Bone morphogenetic protein-2-a potential autocrine/paracrine factor in mediating the stretch activated B-type and atrial natriuretic peptide expression in cardiac myocytes. Mol Cell Endocrinol 399: 9-21, 2015.

91. Pachori AS, Custer L, Hansen D, Clapp S, Kemppa E and Klingensmith J: Bone morphogenetic protein 4 mediates myocardial ischemic injury through JNK-dependent signaling pathway. J Mol Cell Cardiol 48: 1255-1265, 2010.

92. Wang YL, Zhang G, Wang HJ, Tan YZ and Wang XY: Preinduction with bone morphogenetic protein-2 enhances cardiomyogenic differentiation of $\mathrm{c}-\mathrm{kit}^{+}$mesenchymal stem cells and repair of infarcted myocardium. Int J Cardiol 265: 173-180, 2018.

93. Sanders LN, Schoenhard JA, Saleh MA, Mukherjee A, Ryzhov S, McMaster WG Jr, Nolan K, Gumina RJ, Thompson TB, Magnuson MA, et al: BMP antagonist gremlin 2 limits inflammation after myocardial infarction. Circ Res 119: 434-449, 2016.

94. Chen H, Montagnani M, Funahashi T, Shimomura I and Quon MJ: Adiponectin stimulates production of nitric oxide in vascular endothelial cells. J Biol Chem 278: 45021-45026, 2003.

95. Chow WS, Cheung BM, Tso AW, Xu A, Wat NM, Fong $\mathrm{CH}$, Ong LH, Tam S, Tan KC, Janus ED, et al: Hypoadiponectinemia as a predictor for the development of hypertension: A 5-year prospective study. Hypertension 49: 1455-1461, 2007.

96. Amin RH, Mathews ST, Alli A and Leff T: Endogenously produced adiponectin protects cardiomyocytes from hypertrophy by a PPARgamma-dependent autocrine mechanism. Am J Physiol Heart Circ Physiol 299: H690-H698, 2010.

97. Natarajan R, Salloum FN, Fisher BJ, Kukreja RC and Fowler AA III: Hypoxia inducible factor-1 upregulates adiponectin in diabetic mouse hearts and attenuates post-ischemic injury. J Cardiovasc Pharmacol 51: 178-187, 2008. 